\title{
Evaluation of a prototype electronic personal health record for patients with idiopathic thrombocytopenic purpura
}

This article was published in the following Dove Press journal:

Patient Preference and Adherence

9 October 2012

Number of times this article has been viewed

Laurent Chiche'

Alessandra Brescianini'

Julien Mancini²

Hervé Servy ${ }^{3}$

Jean-Marc Durand'

'Service de Médecine Interne,

Centre de Compétence pour la prise en charge des Cytopénies Autoimmunes, Hôpital de la Conception, Marseille, ${ }^{2}$ Service de Santé Publique, Hôpital de la Timone, Marseille, ${ }^{3}$ Association AIMSU, Maison des Associations, La Ciotat, France
Correspondence: Laurent Chiche Service de Médecine Interne, CHU Conception, I47 Boulevard Baille, 13005 Marseille, France

Tel +33491383762

Fax +33491383768

Email laurent.chiche@ap-hm.fr
Background: Patients with rare diseases often lack information about the disease itself and appropriate health care, leading to poor quality of life. Personal health records provide health information which can then be shared between multiple health care providers. Personal health records may also offer a tool for capturing patients' reported outcomes, thus enhancing their empowerment and improving communication with health care professionals. We conducted a pilot study to evaluate the usability of Sanoia, a freely accessible personal health record, which was customized for patients with the rare disease, idiopathic thrombocytopenic purpura (ITP).

Methods: The Sanoia interface was expanded with ITP-specific tools. A prospective study was conducted at the referent center to evaluate the usability of this new interface (referred to here as the "tool") by patients. Forty-three patients were randomized into groups to use or to not use the tool. Its use was evaluated by a specific questionnaire and by surveying individual patient adherence profiles. Evaluation of health-related quality of life using the ITP patient assessment questionnaire, was performed at baseline and after 1,3, and 6 months via postal mail.

Results: The groups were similar at inclusion in terms of characteristics, including global quality of life. During the study period, the tool was used to update the personal records of 19/28 patients $(68 \%)$, with a median of two connections to the tool (range 1-12) plus access by various health care professionals $(\mathrm{n}=22)$. In addition, 15/19 $(78 \%)$ patients used the "personal notes" section at least once. We observed no significant changes in quality of life between patients with or without the tool during the study period.

Conclusion: This pilot study demonstrates the good usability of the new customized Sanoia interface for patients with ITP. Additional studies will increase its usability further, and its interface could be adapted for use with other rare chronic diseases.

Keywords: electronic personal health records, rare diseases, idiopathic thrombocytopenic purpura

\section{Introduction}

Worldwide, there are an estimated 7000 different rare chronic diseases (ie, affecting $<1 / 2000$ people). ${ }^{1}$ In addition to their frequent severity and/or absence of validated treatments, patients with rare diseases often lack information about the disease itself and its appropriate care, which ideally should combine many different spheres of expertise.

Adult immune thrombocytopenic purpura (ITP) is a rare chronic autoimmune disorder characterized by antibody-mediated platelet destruction, often leading to bleeding symptoms that may range from mild bruising and mucosal bleeding to severe 
hemorrhage. ${ }^{2}$ Patients also often complain of fatigue and report poor health-related quality of life. ${ }^{3}$ The treatmentrelated side effects and quality of life for these patients, including limitations to occupation and daily activities, have only recently become a focus of clinical research.

Personal health records and their potential application in rare diseases have rarely been evaluated. Yet, these can provide health information and allow information to be shared between multiple health care providers, which is particularly important when patients are away from their referent center. Also, personal health records offer tools for capturing patientreported outcomes (eg, pain, symptoms, self-scoring), which may enhance patient empowerment as well as improve communication with health care professionals.

In France, Sanoia has recently developed a freely accessible personal health record interface that fully addresses privacy concerns and is already being used by $>120,000$ patients. ${ }^{4}$ We designed a prototype specifically customized for patients with ITP and conducted a pilot 6-month study to evaluate its usability and potential impact on quality of life.

\section{Materials and methods} Creation of the tool

This study was conducted at the referent center, the Hospital Conception (Centre de Compétence, Marseille, France), which diagnoses and manages ITP. Sanoia has developed a web tool integrated with electronic personal health records, which offers full privacy protection using an innovative anonymity technique. ${ }^{4}$ The tool already includes numerous factors related to chronic disease, ie, vaccination records, allergies, prescription history, previous symptoms (Figure 1A), and medical test results (Figure 1B). Once the patient has created his/her personal health record, they receive a unique personal identifier online that they can keep with them and communicate to a physician or health care provider (Figure 1C). The latter can then access the patient's medical information in four languages (Figure 1D). Notably, only the patient has the personal password needed to modify and update the content of their personal health record.

In collaboration with physicians from the center, the existing interface of the Sanoia was expanded with ITP-specific tools, which included a link to ITP-related web resources that had been validated by physicians (Figure 2A), and an online emergency protocol, created from updated national recommendations. $^{7}$ The Sanoia interface has also been modified to allow patients to take personal (bloc) notes of symptoms, medications, and any intercurrent events (Figure 2B). The new interface is hereafter referred to as the "tool".

\section{Prototype evaluation}

The principal aim of this 6-month prospective study was to evaluate the usability of the tool by patients with ITP.

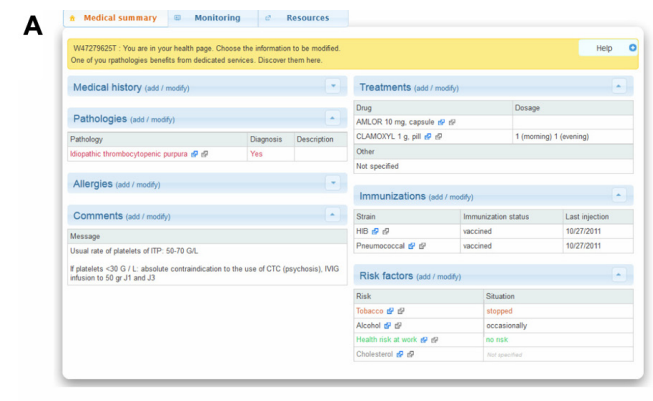

B

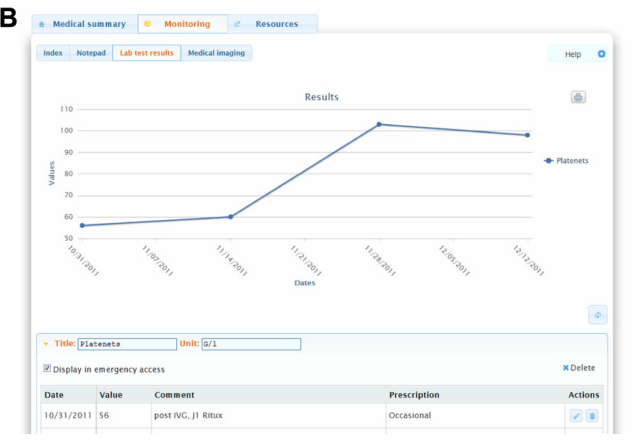

C

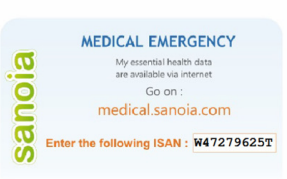

D

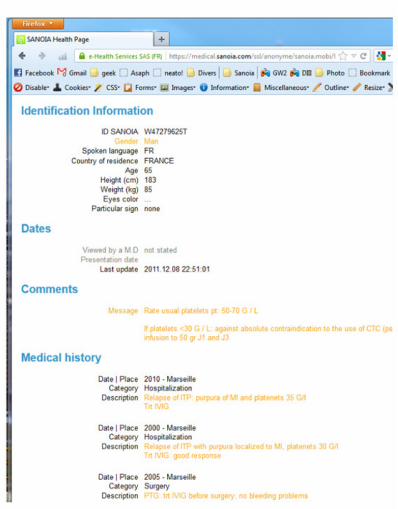

Figure I Sanoia interface. The Sanoia interface already includes various information corresponding to vaccination records, allergies, prescription history, and previous symptoms (A), and medical test results (B). Once the personal health record is created, the patient receives a personal unique identifier online that he/she can keep with them (C). This can be communicated to any health care provider, who can then access the medical information in four languages (D). 
A

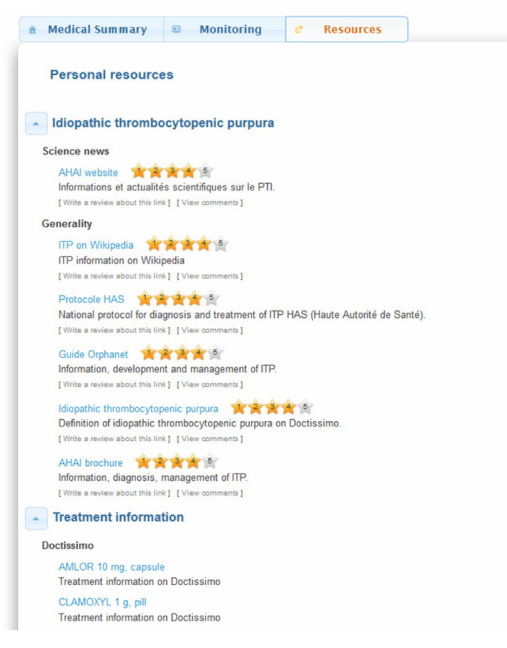

B

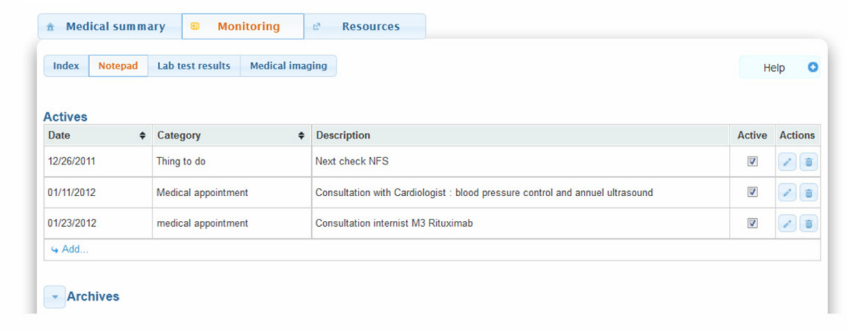

Figure 2 Sanoia options in the customized interface for patients with ITP (the tool). The existing interface of Sanoia was expanded with ITP-specific tools, including addition of a link to ITP-related web resources validated by physicians (A), and a section for personal (bloc) notes for symptoms, medications, or intercurrent events (B). Abbreviation: ITP, immune thrombocytopenic purpura.

The secondary aim was to evaluate its potential impact on quality of life. To avoid any bias caused by selection of patients who might be more confident with the use of computers, patients with ITP hospitalized at the center between 2000 and 2010 were randomly and directly contacted by telephone to participate in the study. For this pilot study, we planned to enroll between 10 and 15 patients per group (see below). Eligible patients were men or women aged between 18 and 75 years with a diagnosis of chronic ITP according to the American Society of Hematology guidelines, ${ }^{3}$ permanent web access, and no neuropsychiatric conditions. After providing their written consent, the patients enrolled were randomized into three groups.

Groups 2 and 3 had personal health records initiated at the center during their first visit. Basic instructions concerning the use of the study tool were provided by resource personnel, and all patients received a printed manual (see Supplementary data). Those assigned to group 3 were also able to contact resource personnel (by phone and/or email) throughout the study period. The usability of the tool was evaluated by a specific questionnaire (including use of the tool by the patient alone or with a health care professional) and, more objectively, by surveying the number of individual times the patients connected with the tool, either to update personal records or to use it with a health care professional. After 3 months, the usage profiles were determined as previously reported. ${ }^{5}$

Briefly, patients were classified as nonadherent, adherent, or very adherent if they connected on $<2,2$, or $\geq 3$ occasions with the tool, respectively (not including access by professionals). Demographic and medical data, as well as evaluation of health-related quality of life, using the ITP patient assessment questionnaire ${ }^{4}$ were recorded at inclusion and at 1, 3, and 6 months via postal mail (see questionnaire in the Supplementary data). Group 1 comprised controls and had no access to the tool, and these patients were only evaluated for quality of life.

\section{Results}

Forty-three of 72 patients who were contacted (15 were not interested and 14 did not fulfill the inclusion criteria), were enrolled and randomized into three groups $(n=15, n=14$, and $\mathrm{n}=14$, respectively, in groups 1,2 , and 3 ). At inclusion, clinical and biological characteristics, as well as global quality of life, were similar between the groups (Tables 1 and 2).

Results concerning the usability of the tool during the study period are reported in Table 2 . Data reported by patients in the questionnaires were in complete agreement with the number of connections to the tool recorded during the study period. The tool was used to update personal records by 19/28 patients (68\%), with each of the 19 patients making a median of two connections (range 1-12). In month 3, heterogeneous usage profiles were observed between patients from groups 2 and 3, which were classified as nonadherent (less than two connections), adherent (two connections), or very adherent (at least three connections) in $28 \%, 40 \%$, and $32 \%$, respectively. Except for being older, no other differences were observed between very adherent and nonadherent patients (mean age 57 versus 44 years respectively, $P=0.04$ ) with regards to their characteristics at inclusion. 
Table I Patient characteristics at enrolment

\begin{tabular}{|c|c|c|}
\hline & $\begin{array}{l}\text { Group I } \\
(n=15)\end{array}$ & $\begin{array}{l}\text { Groups } 2 \\
\text { and } 3(n=28)\end{array}$ \\
\hline Age (years) & $44(19-67)$ & $49(2 I-73)$ \\
\hline Gender (female), \% & 73.3 & 75 \\
\hline Mean duration of ITP, (years) & 13 & 9 \\
\hline Splenectomy, \% & 33.3 & 28.6 \\
\hline Chronic treatments, ${ }^{*} \mathrm{n}$ & 7 & 8 \\
\hline Steroids & 3 & 5 \\
\hline TPO agonists & $\mathrm{I}$ & 2 \\
\hline Other** & 3 & I \\
\hline Platelets (Giga/L) & $120(4-450)$ & $160(16-453)$ \\
\hline
\end{tabular}

Notes: Unless otherwise specified, results are given as their medians (range). *Intercurrent treatments (ie, short corticosteroid therapy initiated for a flareup of the disease) were not taken into account. **disulone, hydroxychloroquine.

Abbreviations: ITP, immune thrombocytopenic purpura; TPO, thrombopoietin.

During the study period, patients used the tool with various health care professionals: general practitioners $(n=11)$, dentists $(n=2)$, nurses $(n=1)$, specialists (cardiologist, internist, or ophthalmologist, $n=5)$, or physiotherapists $(n=3)$. Notably, patients did not report any refusal from health care professionals to use information from the tool during a consultation. In addition, 15/19 (78\%) used the personal notes section at least once for various reasons (to report symptoms or medical events, to write questions to ask their doctor).

Of note, patients from group 3 had no contact with resource personnel, likely because they received adequate information through the instructions provided during initiation of the tool and in its dedicated manual. During the study period, we observed no significant changes in quality of life between patients from group 2 and 3 , or in patients from group 1 who did not use the tool (Table 2).

Table 2 Usability of the study tool and impact on quality of life

\begin{tabular}{|c|c|c|c|}
\hline & $\begin{array}{l}\text { Group I } \\
(n=15)\end{array}$ & $\begin{array}{l}\text { Group } 2 \\
(n=14)\end{array}$ & $\begin{array}{l}\text { Group } 3 \\
(n=14)\end{array}$ \\
\hline \multicolumn{4}{|l|}{ Usability of the tool } \\
\hline Users $^{*}$ & - & $19(68 \%)$ & \\
\hline Connections ${ }^{\#}$ & - & $2(1-12)$ & \\
\hline Personal notes ${ }^{* *}$ & - & 15 (78\%) & \\
\hline \multicolumn{4}{|l|}{ Impact on QoL \#\# } \\
\hline $\begin{array}{l}\text { Overall QoL at } \\
\text { baseline (M0) }\end{array}$ & $89(27,100)$ & $98(36,100)$ & $92(16,100)$ \\
\hline $\begin{array}{l}\text { Change in QoL, } \\
\text { baseline to MI }\end{array}$ & $0(-27,16)$ & $-3(-47,24)$ & $-2(-18,27)$ \\
\hline $\begin{array}{l}\text { Change in QoL, } \\
\text { baseline to M3 }\end{array}$ & $0(-27,33)$ & $-20(-42,24)$ & $-2(-18,20)$ \\
\hline $\begin{array}{l}\text { Change overall QoL, } \\
\text { baseline to M6 }\end{array}$ & $-7(-49,7)$ & $-13(-56,-1)$ & $-9(-20,2)$ \\
\hline
\end{tabular}

Notes: *At least one connection to the tool during the study period; "Number of connections by users; **at least one use of the "personal notes" section by users; \#QoL (quality of life) evaluated using the immune thrombocytopenic purpura patient assessment questionnaire (maximum score of 100). ${ }^{3}$ Results are shown as the median and range.

\section{Discussion}

The use of electronic personal health records has recently increased in spite of concerns regarding the privacy of recorded data. This first pilot study confirms the usability of a self-managed personal health record interface which was specifically customized for patients with a specific rare disease, ie, ITP. Indeed, $68 \%$ of patients used the tool effectively, and $72 \%$ of these met criteria for good and very good adherence. Also, the tool was not only used for updating the personal health record, but also during consultations with various health care professionals and to make personal notes.

The usefulness of this tool relies on patients' understanding and using their records appropriately. The help provided directly by the hospital during initiation of the tool, as well as the creation of a specific manual to guide first users, were probably key factors in enabling its good adoption. However, we observed varying levels of usage of the tool, so additional research is needed to identify possible barriers to adoption. Interestingly, a previous study has reported increased usability of a similar tool by patients with asthma who used mobile phones instead of computers. ${ }^{6}$ Sanoia have recently implemented an interface for mobile phones. Thus, future studies involving the tool could also evaluate the impact of this parameter on the usability by patients with ITP.

During the study period, we did not observe a significant impact on quality of life. This negative result may be linked to our small sample size, which precluded any statistical per protocol analyses (ie, studying the impact of quality of life only in those who could effectively use the tool). Alternatively, the impaired quality of life at inclusion of our patients was not as severe as that reported in other studies. ${ }^{7}$ During the study period, none of the enrolled patients presented with a flare-up of their disease. Thus, the actual impact of the tool on patient health outcomes and well-being should be evaluated further in more patients, with other severe/active diseases, and for a longer period.

In conclusion, we found that patients with ITP, a rare disease, adapted satisfactorily to using the electronic personal health record with the Sanoia interface. Even though this study did not show a significant improvement in health-related quality of life, it has demonstrated the usability of this customized and freely accessible Sanoia interface, which could potentially be adapted for use by patients with other rare diseases.

\section{Acknowledgment}

We thank all patients who participated in this study, as well as the physicians involved in designing the tool. 


\section{Disclosure}

Hervé Servy is the founder of Sanoia, and received a grant from Amgen to support this work. Other authors have no conflicts of interest to report.

\section{References}

1. Orphanet: the portal for rare diseases and orphan drugs. Available from: http://www.orpha.net. Accessed September 10, 2010.

2. George JN, Woolf SH, Raskob GE, et al. Idiopathic thrombocytopenic purpura: a practice guideline developed by explicit methods for the American Society of Hematology. Blood. 1996;88:3-40.

3. Mathias SD, Bussel JB, George JN, McMillan R, Okano GJ, Nichol JL. A disease-specific measure of health-related quality of life for use in adults with immune thrombocytopenic purpura: its development and validation. Health Qual Life Outcomes. 2007;5:11.
4. Sanoia. La fiche Santé anonyme. Available from: http://www.sanoia.com/ fiche-sante/. Accessed May 3, 2012.

5. Trijau S, Servy H, Selamnia A, Pradel V, Lafforgue P, Pham T. Personal health records in rheumatoid arthritis: quality and adhesion factors. Arthritis Rheum. 2011;63:S10.

6. Anhøj J, Moldrup C. Feasibility of collecting diary data from asthma patients through mobile phones and SMS (short message service): response rate analysis and focus group evaluation from a pilot study. J Med Internet Res. 2004;6:e42.

7. George JN, Mathias. SD, Go RS, et al. Improved quality of life for romiplostim-treated patients with chronic immune thrombocytopenic purpura: results from two randomized, placebo-controlled trials. $\mathrm{Br} \mathrm{J}$ Haematol. 2009;144:409-415. 


\section{Appendix}

\section{Patient questionnaire}

Surname:

Name:

ISAN:

\section{Physical health}

\section{Symptom scale}

(10-point Likert scale from all the time to never)

In the past four weeks how often did you:

- Have either bruising or petechiae (broken blood vessels)?

- Have wounds or scars from blood tests, injections, or intravenous needles?

- Have blood blisters in your mouth?

- Have bleeding episodes (nose bleeds, gum bleeds)?

- Have muscle aches?

- Have cramps in your legs?

\section{Fatigue/sleep scale}

(10-point Likert scale from all the time to never)

In the past four weeks how often did ITP or its treatment:

- Cause you to have difficulty falling asleep at bedtime?

- Cause you to awaken during the night?

- Cause you to feel sleepy during the daytime?

- Cause you to feel physically fatigued?

\section{Bother scale}

In the past four weeks:

11. How often did you feel physically unattractive due to bruising, scarring, wounds, or effects of ITP medications? (10-point Likert scale from all the time to never)

12. Overall, to what extent have ITP and its treatment affected your physical health? (10-point Likert scale from extremely to not at all)

13. Overall, how bothered have you been by the effect of ITP and its treatment on your physical health? (10-point Likert scale from extremely to not at all)

\section{Activity scale}

(10-point Likert scale from extremely to not at all) In the past four weeks:

- How much have your ITP symptoms or the effects of its treatments interfered with your ability to exercise?

- To what extent has having ITP limited the types of physical or sporting activities you participate in?

- Did you participate in sport? (yes/no)

- Are you fearful of doing sport because of ITP? (yes/no)

\section{Emotional health \\ Psychological scale}

In the past four weeks:

- How often did you feel like you have no control over your health because of your ITP or its treatments? ( 10-point Likert scale from all the time to never)

- How often did you feel like you were unable to manage stress because of ITP or its treatments? (10-point Likert scale from all the time to never)

- How often did you have feelings of sadness or depression because of ITP or its treatments? (10-point Likert scale from all the time to never)

- Overall, how much has ITP or its treatments affected you psychologically (mental state, emotions)? (10-point Likert scale from extremely to not at all)

- Overall, how bothered have you been by the effect that ITP or its treatments has had on you psychologically (mental state, emotions)? (10-point Likert scale from extremely to not at all)

\section{Fear scale}

(10-point Likert scale from extremely fearful to not at all fearful)

In the past four weeks:

- How often have you been fearful of having a bleeding episode (eg, nose bleeds, gum bleeds)?

- How fearful have you been of death or dying?

- How fearful have you been of being too far away from your doctor in case you needed medical help?

- How fearful have you been about getting an infection?

- How fearful have you been of needing to have emergency surgery (due to concerns about bleeding during surgery)

\section{Overall quality of life}

In the past four weeks:

- Overall, to what extent has ITP and its treatments affected your quality of life? (10-point Likert scale from extremely to not at all)

- Overall, how bothered have you been by the effect of ITP and its treatments on your quality of life? (10-point Likert scale from extremely to not at all)

- I have made significant changes to my lifestyle because I have ITP (10-point Likert scale from strongly agree to strongly disagree)

- My ITP prevents me from doing things in life that I want to do (10-point Likert scale from strongly agree to strongly disagree) 
- My ITP prevents my spouse, partner, or family members from doing things in life that they want to do (10-point Likert scale from strongly agree to strongly disagree).

\section{Social activity}

In the past four weeks:

- How often has having ITP limited your ability to participate in social activities? (10-point Likert scale from all the time to never)

- How often have you avoided social activities to limit your exposure to infection? (10-point Likert scale from all the time to never)

- How bothered were you by what people might think about your bruising or scarring? (10-point Likert scale from extremely to not at all)

- To what extent have you been unable to lead a normal social life because of your ITP? (10-point Likert scale from extremely to not at all)

\section{Women's reproductive health (to be completed by women only)}

Menstrual symptom subscale (10-point Likert scale from extremely to not at all)

Thinking about your last period:

- How bothered were you by heavier bleeding than before having ITP?

- How bothered were you by bleeding for more days than before having ITP?

- How bothered were you by more pain than before having ITP?

Fertility subscale (10-point Likert scale from extremely to not at all)

- How much has having ITP made it less likely that you would get pregnant?

- How much has having ITP made it less likely that you would give birth?
- How much has having ITP made it less likely that you would adopt?

Work (10-point Likert scale from extremely to not at all, with a not applicable option)

Since you were diagnosed:

- To what degree has ITP negatively interfered with your choice of careers?

- How much has ITP negatively interfered with your ability to get a promotion at your job?

- How much has ITP negatively interfered with your relationship with coworkers?

- How fearful have you been of losing your job because of your ITP?

\section{Supplementary questions}

Since your last ITP-PAQ:

- How many platelet tests have you have had done on average? (six-point Likert scale from $<1$ to $>4$ )

- Have you travelled more than $200 \mathrm{~km}$ far away from your residence? (yes/no)

- Are you fearful of travelling because of ITP? (yes/no)

- Have you travelled abroad? (yes/no)

- Are you fearful of travelling abroad because of ITP? (yes/no)

\section{Your medical or paramedical consultations since your last questionnaire \\ Date}

Type of caregiver

Consultation concerning ITP ?(yes/no)

Have you shown your Sanoia tool? (yes/no)

Has your Sanoia tool been useful to the consultation? (yes/no)

Comments 


\section{QUESTIONNAIRE MEDICAL à 1 mois}

Nom: SERVY

Prén. : Hervé

ISAN : H76868527T

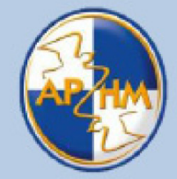

\section{Etat physique}

\section{Echelle des symptômes}

Durant les 4 dernières semaines, avez-vous eu souvent

1 Des hématomes ou pétéchies

2 Des plaies ou stigmates à cause d'analyses sanguines, injections ou aiguilles pour IV?

3 Des bulles hémorragiques dans la bouche?

4 Des saignements (du nez, gencives, etc.)?

5 Des douleurs musculaires?

6 Des crampes dans les jambes?

Echelle de fatigue / sommeil

Durant les 4 dernières semaines, le PTI ou son traitement vous a-t-il fréquemment :

7 Causé des difficultés pour vous endormir?

8 Réveillé durant la nuit?

9 Rendu somnolent durant la journée?

10 Fait vous sentir fatigué physiquement?

\section{Echelle de contrainte/ennui} Durant les 4 dernières semaines:

11 Vous êtes vous senti souvent peu attirant à cause des hématomes, plaies, cicatrices ou effets du traitement?

12 D'une manière générale, jusqu'à quel point le PTI et son traitement ont-ils un impact sur votre état physique?

13 D'une manière générale, avez-vous été tracassé par l'impact du PTI et de son traitement sur votre état physique?

Echelle des activités

Durant les 4 dernières semaines:

14

Jusqu'à quel point les symptômes du PTI ou les effets du traitement ont-ils interféré sur votre capacité à faire des activités?

15 Jusqu'à quel point le PTI limite-t-il votre participation à des activités physiques ou sportives?

15 bis Avez-vous pratiqué du sport ?

15 tri Est-ce que pratiquer du sport est une source d'inquiétude vis-à-vis du PTI ? à renvoyer au 15/03/2012

par enveloppe pré timbrée jointe

ou par courrier simple au Dr CHICHE Hopital de la Conception, Médecine Interne 137 bd Baille, 13005 Marseille
Jamais $\longrightarrow$ Souvent $\longrightarrow$ Tout le temps $\begin{array}{llllllllll}0 & 1 & 2 & 3 & 4 & 5 & 6 & 7 & 8 & 9\end{array}$

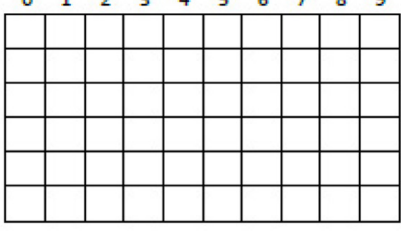

Jamais $\longrightarrow$ Souvent $\longrightarrow$ Tout le temps

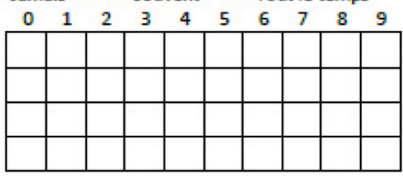

Jamais $\longrightarrow$ Souvent $\longrightarrow$ Tout le temps $\begin{array}{llllllllll}0 & 1 & 2 & 3 & 4 & 5 & 6 & 7 & 8 & 9\end{array}$ Pas du tout $\longrightarrow$ Extrêmement

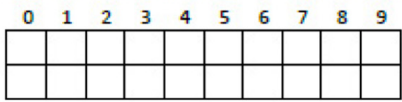

Pas du tout $\longrightarrow$ Extrêmement

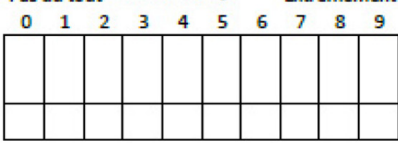

OUI

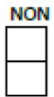

\section{Etat émotionnel}

Echelle psychologique

Durant les 4 dernières semaines:

16 Avez-vous souvent senti ne plus avoir le contrôle de votre santé à cause de votre PTI ou de son traitement? Jusqu'à quel point ne vous êtes vous pas senti capable de gérer le stress à cause de votre PTI ou de son traitement?

18 Jusqu'à quel point vous êtes vous senti triste ou déprimé à cause de votre PTI ou de son traitement?

19 D'une manière générale, jusqu'à quel point le PTI ou son traitement vous affecte-t-il psychologiquement (mental, émotion)? PTI ou de son traitement?

\section{Echelle des peurs}

Durant les 4 dernières semaines:

21 Jusqu'à quel point avez-vous eu peur d'avoir des saignements (de nez, gencive,etc.)?

22 Jusqu'à quel point avez-vous eu peur de la mort ou de mourir?

23 Jusqu'à quel point avez-vous été angoissé à l'idée d'être loin de votre médecin en cas de problème médical?

24 Jusqu'à quel point avez-vous eu peur d'avoir une infection?

25 Jusqu'à quel point avez-vous eu peur d'avoir recours à la chirurgie d'urgence?
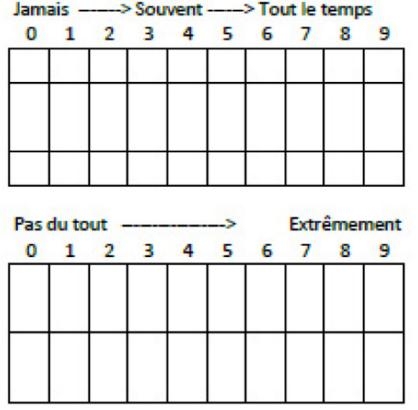

Pas du tout craintif $\longrightarrow$ Extrèmement craintif

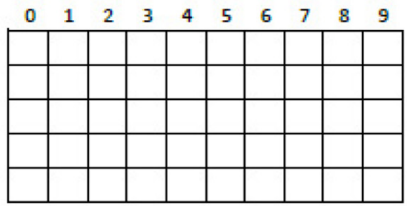




\section{QUESTIONNAIRE MEDICAL à 1 mois page 2}

\section{Qualité de vie globale}

Durant les 4 dernières semaines:

26 D'une manière générale, comment le PTI ou son traitement affecte-t-il votre qualité de vie?

27 D'une manière générale, jusqu'à quel point avez-vous été ennuyé à cause de l'impact du PTI ou de son traitement sur votre qualité de vie?

28 J'ai changé ma façon de vivre à cause du PTI.

29 Mon PTI m'empêche de faire certaines choses dont j'ai envie.

30

Mon PTI empêche mon conjoint, mes partenaires ou les membres de ma famille de faire des choses qu'ils aimeraient faire.

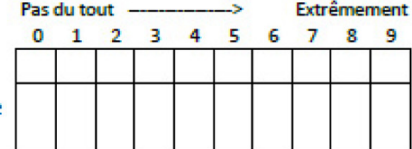

Pas du tout d'accord $\rightarrow$ Extrêment d'accord

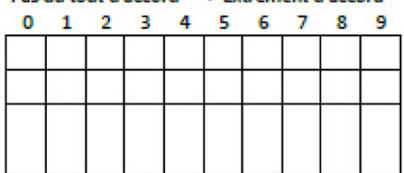

\section{Activité sociale}

Durant les 4 dernières semaines:

31 Le PTI vous a-t-il souvent limité dans vos participations à des activités sociales?

32 Avez-vous souvent évité de faire des activités sociales pour limiter votre exposition aux infections?

Jamais $\longrightarrow$ Souvent $\rightarrow$ Tout le temps

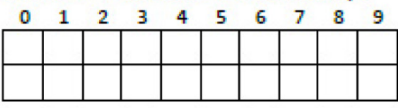

Pas du tout $\longrightarrow$ Extrêmement $\begin{array}{llllllllll}0 & 1 & 2 & 3 & 4 & 5 & 6 & 7 & 8 & 9\end{array}$

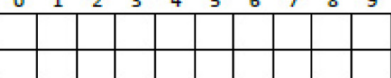

33 Jusqu'à quel point êtes-vous ennuyé par ce que les gens peuvent penser des hématomes ou cictrices liés au PTI?

34 Jusqu'à quel point, avez-vous été incapable de mener une vie sociale normale à cause de votre PTI?

\section{Cycle menstruel (pour les femmes uniquement)}

Echelle des symptômes menstruels

En pensant à vos dernières règles:

35 Jusqu'à quel point êtes-vous embarrassée d'avoir des saignements plus abondants qu'avant votre PTI?

36 Jusqu'à quel point êtes-vous embarrassée parce qu'elles durent plus de jours qu'avant votre PTI?

37 Jusqu'à quel point êtes-vous embarrassée parce qu'elles sont plus douloureuses qu'avant votre PTI?

\section{Echelle de fertilité}

en général

38 Jusqu'à quel point le PTI vous a-t-il rendue réticente à l'idée d'être enceinte?

39 Jusqu'à quel point le PTI vous a-t-il rendue réticente à l'idée d'accoucher?

40 Jusqu'à quel point le PTI vous a-t-il rendue réticente à l'idée d'adopter?
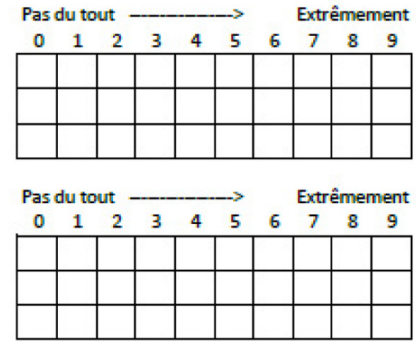

\section{Activité professionnelle}

Depuis le diagnostic:

41 A quel point le PTI a-t-il interféré avec vos choix de carrière?

42 Jusqu'à quel point le PTI a-t-il interféré de manière négative avec la possibilité d'avoir une promotion?

43 Jusqu'à quel point le PTI a-t-il interféré de manière négative dans vos relations professionnelles?

44 Jusqu'à quel point avez-vous craint de perdre votre travail à cause de votre PTI?

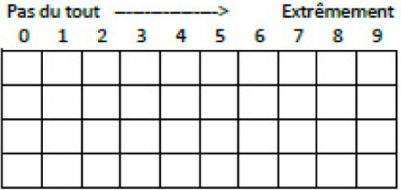

\section{Question suplémentaires}

depuis votre dernier questionnaire

45 Combien de Numération des plaquettes avez-vous réalisé en moyenne? (par mois)

46 Avez-vous effectué des déplacements à plus de $200 \mathrm{~km}$ de chez vous en France ?

47 Est-ce que cette situation est une source d'inquiétude vis-à-vis du PTI ?

48 Avez-vous effectué des déplacements à l'étranger ?

49 Est-ce que cette situation est une source d'inquiétude vis-à-vis du PTI ?
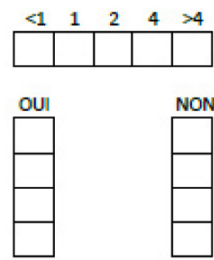


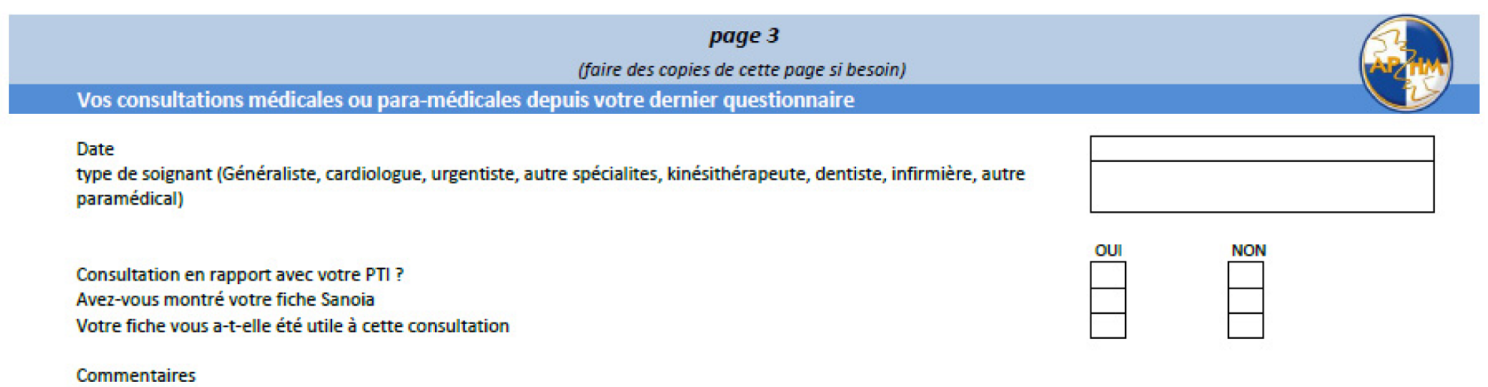

Date
type de soignant (Généraliste, cardiologue, urgentiste, autre spécialites, kinésithérapeute, dentiste, infirmière, autre paramédical)

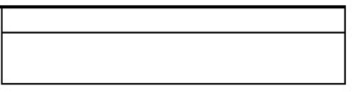

Consultation en rapport avec votre PTI ? Avez-vous montré votre fiche Sanoia

Votre fiche vous a-t-elle été utile à cette consultation

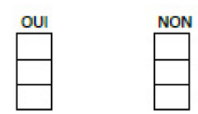

Commentaires

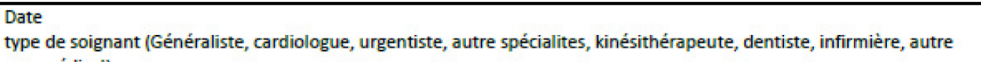
paramédical)

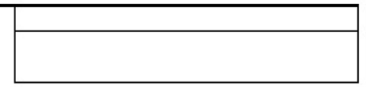

Consultation en rapport avec votre PTI?

Avez-vous montré votre fiche Sanoia

Votre fiche vous a-t-elle été utile à cette consultation

Commentaires

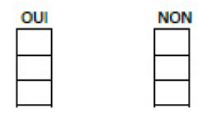

Date

type de soignant (Généraliste, cardiologue, urgentiste, autre spécialites, kinésithérapeute, dentiste, infirmière, autre paramédical)

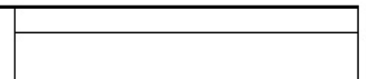

Consultation en rapport avec votre PTI ?

Avez-vous montré votre fiche Sanoia

Votre fiche vous a-t-elle été utile à cette consultation

Commentaires

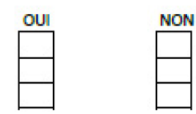

Date paramédical)

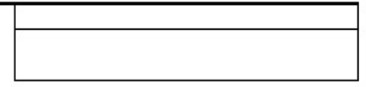

Consultation en rapport avec votre $\mathrm{PTI}$ ?

Avez-vous montré votre fiche Sanoia

Votre fiche vous a-t-elle été utile à cette consultation

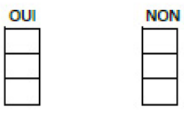

Commentaires

Patient Preference and Adherence

Dovepress

\section{Publish your work in this journal}

Patient Preference and Adherence is an international, peer-reviewed, open access journal focusing on the growing importance of patient preference and adherence throughout the therapeutic continuum. Patient satisfaction, acceptability, quality of life, compliance, persistence and their role in developing new therapeutic modalities and compounds to optimize clinical outcomes for existing disease states are major areas of interest. This journal has been accepted for indexing on PubMed Central. The manuscript management system is completely online and includes a very quick and fair peer-review system. Visit http://www.dovepress.com/ testimonials.php to read real quotes from published authors.

Submit your manuscript here: http://www.dovepress.com/patient-preference-and-adherence-journal 